\title{
Opinions and Attitudes of Secondary School Mathematics Teachers Towards Technology
}

\author{
Mehmet Alper Ardiç* \\ Faculty of Arts and Sciences, Adlyaman University, Adlyaman, Turkey \\ ORCID: 0000-0001-9816-4422
}

Article history

Received:

25.10.2020

Received in revised form: 11.01.2021

Accepted:

29.01.2021

Key words:

IT acceptance;

Mathematics education;

Secondary school education;

Teachers' attitude;

Teachers' opinion
The literature on the barriers encountered in the use of technology in education indicates that the internal barriers have a deterministic effect within this process. Therefore, it is important to determine the way teachers use technology as well as their opinions and attitudes towards technology in order to ensure effective use of technology in mathematics education. This study aims to determine the opinions and attitudes of secondary school mathematics teachers towards using technology in mathematics education. The convergent parallel design of a mixed methods study was used. The study included the participation of 57 teachers, who were determined on a voluntary basis using the convenience sampling method, from 22 different high schools in Turkey. A written opinion form and The Scale of Attitudes Towards Technology were used as data collection tools. The qualitative data obtained were analysed using descriptive and content analysis methods; quantitative data were analysed using multivariate analysis of variance. It was understood that the participants often used only smartboards in their lessons and they preferred teacher-centred classroom applications, which did not involve the hardware and software that allowed student interaction. It was found that the attitudes of mathematics teachers towards technology were "positive" which had a positive effect on using technology in lessons. It was observed that the attitudes of teachers towards technology did not change according to the training they received on using technology in lessons. It was concluded that the attitudes of teachers differed significantly across the scale or in various factors according to their age, the frequency of technology use in their lessons, the variety of hardware and software they use, and their opinions about the use of technology by the students. It can be argued that the positive attitudes of teachers towards technology had a positive effect on using technology in lessons.

\section{Introduction}

In modern day, where problems that are different from those encountered by the previous generations are experienced, there is an increasing need for individuals who value mathematics, have advanced mathematical thinking power, and can use mathematics in modeling and problem solving (Republic of Turkey Ministry of National Education [MoNE], 2013). For example, the developments and requirements in areas such as coding, big data, block chain and others have redirected the research problems of mathematics, thus increasing the requirement for individuals with advanced mathematic skills. In this context, the innovations that the effective use of technological tools could provide for mathematics 
education should be taken into consideration. Enabling students to interact with technological tools such as computers, tablet computers, and smart (interactive) boards with appropriate software and content in mathematics education could activate their high-level cognitive skills, and they could construct their own mathematical knowledge. Rather than replacing mathematical skills with technology, the aim is to ensure that mathematical thinking becomes accessible for all students regardless of their skill levels. Hence, students would be able to work on real/realistic problems in line with the requirements of the age, and use the time they save by avoiding long mathematical operations for reasoning and creative thinking.

The literature on the barriers encountered in the use of technology in education indicates that these barriers consist of two orders: external and internal barriers (Ertmer, 1999). Barriers that are independent from the teacher, such as the lack of access to the hardware and software required in teaching, incompetent teaching plans, and lack of necessary technical and administrative support, are external barriers. Internal barriers are the attitudes and beliefs of teachers towards themselves as well as the teaching and learning activities. Attitudes of teachers towards technology (ATTT), their self-confidence, beliefs about current teaching and classroom routines, and beliefs in change could be listed as examples of internal barriers. Ertmer (1999) stated that overcoming internal barriers to using technology in education was more difficult than overcoming external barriers. Considering that external obstacles are generally independent from teachers, it could be argued that policy makers and education administrators should make the main effort to overcome these very barriers. In this context, many governments have spent significant amounts of money and human resources in the last 30 years trying to overcome external barriers in order to improve the technological opportunities in schools (Etmer et al., 2012; Göktaş, Gedik \& Baydaş, 2013). Increasing Opportunities and Improving Technology Movement (FATIH), which started in Turkey in 2011, is an example of these attempts. Within the scope of the FATIH Project, classrooms were equipped with smartboards and broadband Internet access, and tablet computers were distributed to teachers and students in many schools. In the project, it was aimed to improve the technical infrastructures of the classrooms, enable the effective use of technology in education activities, address more senses within the learning and teaching process, and ensure equality of opportunity in education. In addition, in-service trainings were held and web platforms were created for teachers within the project to ensure integration of technology in their lessons and to create e-content (MoNE, 2020). Previous studies indicate that the external barriers to the use of technology in education have been considerably overcome thanks to the projects, such as FATIH, that are carried out in many countries; however, the internal barriers still have a deterministic effect within this process (Ertmer et al., 2012; Göktaş, Gedik \& Baydaş, 2013; Ottenbreit-Leftwich, Liao, Sadik \& Ertmer, 2018). Therefore, it is important to determine the way teachers use technology as well as their opinions and attitudes towards technology in order to ensure effective use of technology in mathematics education. However, this study and similar studies could inspire policy makers to more effectively plan financial and human resources to be spent on integration of technology in education.

Although the internal barriers, such as negative attitudes towards the integration of technology in education, may seem rather abstract or phenomenological, they are mainly related to behaviours. Attitude can be briefly expressed as "the tendency attributed to an individual, which constructs his/her regular opinions, feelings and behaviours about a psychological object" (Kağıtçıbaşı, 1999). Oskamp and Schultz (2005) suggested that the attitude towards an individual, object, situation or case consisted of a three-dimensional structure, being cognitive, affective and behavioural; thus, it is expressed in cognitive, emotional and behavioural reactions. In this respect, the attitude of an individual towards a 
particular subject could be understood by reviewing his/her opinions and behaviours through which s/he expressed his/her thoughts, emotions or behaviours. Therefore, in order to determine the attitudes of mathematics teachers towards using technology in their lessons more significantly, it would be useful to consider their attitudes and current practices about this subject in addition to using attitude scales.

It is understood that when the ATTT are positive, teachers could easily adapt themselves to the use of technology in learning and teaching processes and integrate them into classroom practices (Buabeng-Andoh, 2012). Many studies concluded that ATTT had a positive effect on predicting and improving technological pedagogical content knowledge competencies, which had an important role in the effective use of technology in lessons (Albayrak Sar1, Canbazoğlu Bilici, Baran \& Özbay, 2016; Buabeng-Andoh, 2012; Çelik \& Yeşilyurt, 2013; Kalemoğlu Varol, 2015; Yulisman et all., 2019). In the literature scan that was carried out about the ATTT, there were not many satisfying studies in terms of their scope. It is understood that the practices of mathematics teachers who use technological tools in their lessons generally replace traditional methods and tools (Bray \& Tangney, 2017; Egan, FitzGibbon \& Oldham, 2013; Ottenbreit-Leftwich et al., 2012; Thinyane, 2010), and they may use a basic level of technology within this process (Ardıç \& İşleyen, 2017a; Avcı, Kula \& Haşlaman, 2019; Bray \& Tangney, 2017; Psycharis, Chalatzoglidis \& Kalogiannakis, 2013). Looking at the studies conducted about the use of technology in education in Turkey, where the FATIH Project, which is defined by MoNE (2020) as the "largest and most comprehensive educational movement in the world about the use of technology in education," was carried out, the attitudes of the participants towards technology were observed to be "high" (Birkollu, Yücesoy, Bağlama \& Kanbul, 2017; Çakır \& Oktay, 2013; Kayalar, 2018; Paşa, Bolat \& Karataş, 2015; Üstün \& Akman, 2015). However, it was seen that the majority of these studies were quantitative studies where the participants were preservice teachers and only scales were used as data collection tools. It was found that the examinations performed in these studies were generally based on the demographic characteristics of participants, and no analysis was performed on the attitudes towards an opinion or a classroom practice. None of the studies conducted nationally in Turkey were found to focus particularly on secondary school mathematics teachers and education. Looking at the existing studies, this study, in which the opinions and attitudes of secondary school mathematics teachers are determined and evaluated collaboratively, is believed to be beneficial in terms of understanding the current situation and contributing to the literature.

\section{Study questions}

In this study, where the opinions and attitudes of secondary school mathematics teachers towards the use of technology in mathematics education were determined, answers to the following study questions were sought:

(1) What are the opinions and attitudes of mathematics teachers on using technology in teaching?

(a) How do teachers use technological tools in lessons and do the ATTT differ according to this usage?

(b) What are the opinions of teachers about the use of technological tools by students and do the ATTT differ according to these opinions?

(c) What kind of training did teachers receive on the use of technology in lessons and do the ATTT differ according to these trainings? 


\section{Methods}

In this research, the convergent parallel design of a mixed methods study was used. In this design, the qualitative and quantitative data were collected and analysed simultaneously, and the findings obtained were examined in order to see whether they supported each other or not (Creswell \& Clark, 2011). The research design of the study is given in Figure 1.

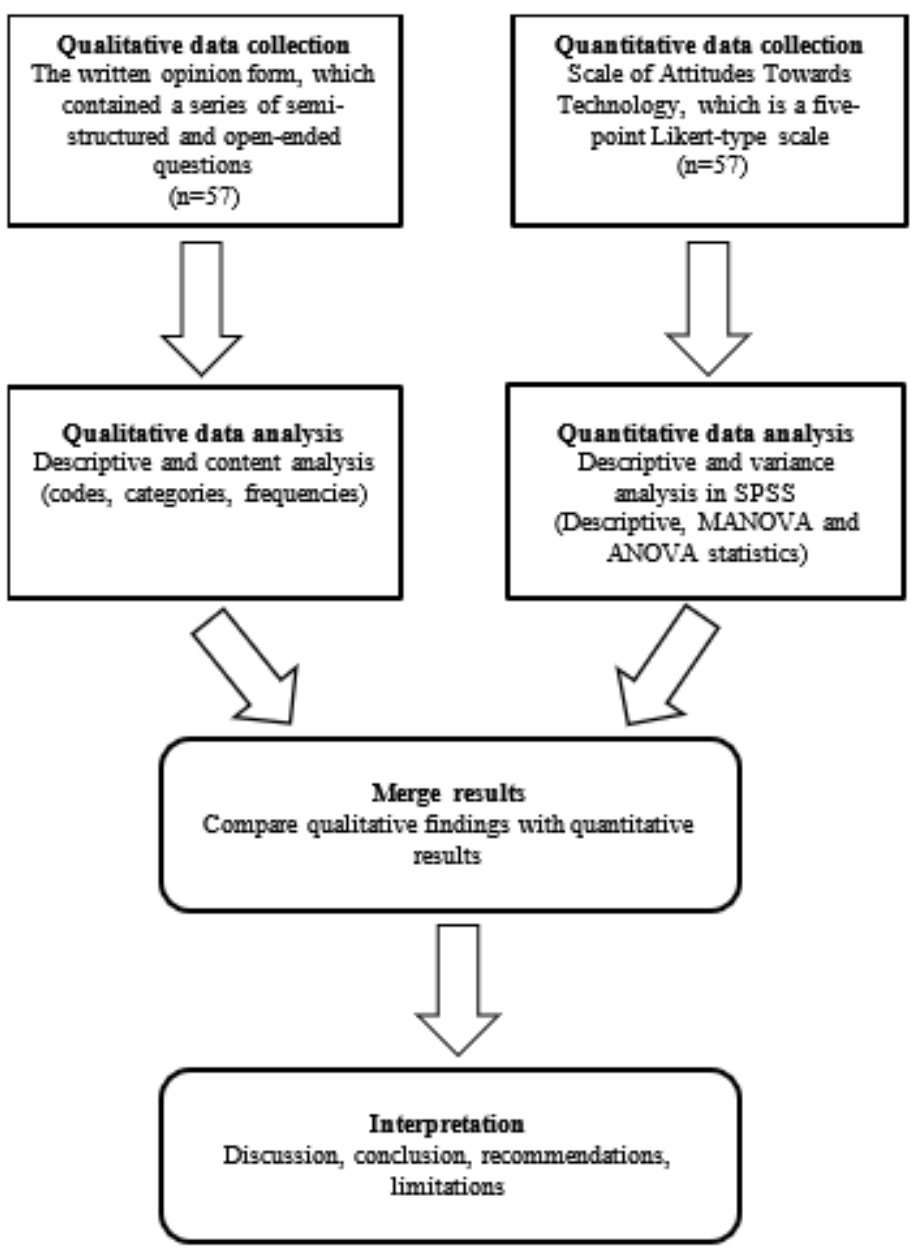

Figure 1. The research design of the study.

\section{Participants}

The study was participated by 57 high school mathematics teachers who were determined on a voluntary basis using the convenience sampling method. Participants were employed in 22 different high schools in a province located in the southeast of Turkey. Technological tools available at the schools of the participants are listed in Table 1.

Table 1. Technological tools available at the schools of teachers.

\begin{tabular}{lll}
\hline Technological Tools & f & \% \\
\hline Smartboard & 53 & 93 \\
Desktop Computer & 39 & 68.4 \\
Tablet Computer in Students & 12 & 21.1 \\
Projector & 8 & 14 \\
Technology classroom & 5 & 8.8 \\
\hline
\end{tabular}




\section{Data Collection and Analysis}

A form that consisted of three parts was used as one of the data collection tools. The first part contained questions about the demographic information of participants and technological facilities available in their schools. In the second part, there was a written opinion form in which the opinions of teachers were taken in order to determine their opinions about the use of technology. The last part of the form included the Scale of Attitudes Towards Technology (SATT) (Yavuz, 2005).

The written opinion form contained a series of semi-structured and open-ended questions to understand how mathematics teachers use technological tools in their lessons as well as what kind of hardware and software they use. The written opinion form was created using the semistructured interview forms developed by the researcher in a previous study (Ardiç \& İşleyen, $2017 \mathrm{~b}, 2017 \mathrm{c}$ ). One of the questions in the written opinion form was: "What are your opinions about the use of a computer or tablet (including appropriate applications) by the students during the lesson?"

Descriptive and content analysis methods were used for the analysis of the qualitative data obtained. The opinions obtained from mathematics teachers were transcribed by the researcher. In the analysis of the opinions, the opinions were first examined per individual, and then the codes, categories, and frequencies were identified through examining them per each question. Afterwards, the data set obtained from each participant were re-examined to obtain the holistic approaches of mathematics teachers. After the codes were arranged according to related categories, they were grouped according to the themes identified by the research questions. To ensure the reliability of the data obtained from written opinions, they were checked by an expert with a doctorate degree in mathematics education, and the identified codes and categories were finalized afterwards. Quotations were made from the opinions of the participants with the aim to explain the codes and categories identified.

In the study, SATT, which was developed by Yavuz (2005), was used as the quantitative data collection tool. SATT, which is a five-point Likert-type scale scored from "1-Strongly disagree" to "5-Strongly agree," consists of five factors and 19 items. These are: "not using technological tools in education (Factor 1, 5 items)," "using technological tools in education (Factor 2, 4 items)," "the effects of technology on educational life (Factor 3, 4 items)," "teaching how to use technological tools (Factor 4, 4 items)," and "evaluating technological tools (Factor 5, 2 items)." Cronbach's Alpha reliability coefficient of SATT was calculated as 0.87. Total correlations of item differentiation and item difficulty calculated separately for 19 items of the scale ranged between 0.24 and 0.68 .

Multivariate analysis of variance (MANOVA) was performed to analyse the data obtained in the study. Before the application of MANOVA during the analysis phase, the relevant data were first checked in terms of their compliance with the required assumptions (normality, multivariate normality, homogeneity of covariance matrices), and no significant violation was found. To determine the source of the differences observed in the dependent variables, variance analysis (ANOVA) was applied for each dependent variable as a follow-up test. In cases where MANOVA results were significant, the follow-up tests were evaluated according to the significance level of $\alpha=.05$. In cases where the results were not significant, the Bonferroni correction was made and $\alpha=.008$ was used as the significance level. In order to understand the independent variables between which the significant differences were observed as a result of the ANOVA tests, the Bonferroni test, which was statistically stronger in comparison of small groups (Type II) and more successful in controlling the Type I error 
rate, was used (Field, 2009).

\section{Findings}

\section{What are the opinions and attitudes of mathematics teachers on using technology in teaching?}

Looking at the opinions of mathematics teachers, it was understood that 49 teachers used technological tools at different frequencies in their lessons, and the remaining 8 did not use them at all (Table 2).

Table 2. Frequency at which teachers use technological tools in lessons

\begin{tabular}{ll}
\hline Frequency of Usage & $\mathbf{N}$ \\
\hline No use & 8 \\
Rarely on certain topics & 3 \\
Several times a month & 9 \\
Several times a week & 9 \\
Almost in every lesson & 28 \\
\hline
\end{tabular}

The majority of teachers stated that their reason for not using technological tools was the lack of equipment (Table 3). Also, when the opinions of the teachers were examined, they were determined to believe that the use of technology was time consuming, was not suitable for mathematics lessons, and would not be beneficial. Some of the relevant opinions of the teachers are as follows:

"I used a smartboard, but it was taking up my time. I saw that the class was always messy. Students listen better when I use chalk. I think, there should not be any technological tools at schools."

"Technology is not suitable for every subject area. There are not many images in mathematics, there are only PDFs and they are like books. Images and animations are better in lessons such as geography and biology."

Table 3. Teachers' reasons for not using technological tools in lessons

\begin{tabular}{ll}
\hline Reasons & $\mathbf{N}$ \\
\hline Lack of equipment & 6 \\
Time consuming & 2 \\
Not beneficial & 2 \\
Students are not ready for technology usage & 2 \\
Not suitable for mathematics lessons & 2 \\
\hline
\end{tabular}

On the other hand, as a result of the descriptive analysis, it was observed that the overall mean scores obtained by the mathematics teachers in SATT was $\mathrm{M}=3.861$ and they had a "positive" attitude towards technology (Table 4). It was also understood that the same result was obtained in all sub-dimensions of the scale.

Table 4. ATTT

\begin{tabular}{lcccl}
\hline SATT Factors & N & M & SD & Attitude \\
\hline Factor 1 & 57 & 3.96 & 0.78 & Positive \\
Factor 2 & 57 & 3.76 & 0.75 & Positive \\
Factor 3 & 57 & 3.83 & 0.70 & Positive \\
Factor 4 & 57 & 3.84 & 0.68 & Positive \\
Factor 5 & 57 & 3.91 & 0.77 & Positive \\
SATT & 57 & 3.86 & 0.50 & Positive \\
\hline
\end{tabular}


In addition, SATT scores of teachers according to their frequency of technology usage are displayed in Table 5.

Table 5. SATT scores of teachers according to their frequency technology usage in their classes

\begin{tabular}{|c|c|c|c|c|c|c|c|c|c|c|c|c|c|}
\hline \multirow{2}{*}{ Frq." } & & \multicolumn{2}{|c|}{ Factor 1} & \multicolumn{2}{|c|}{ Factor 2} & \multicolumn{2}{|c|}{ Factor 3} & \multicolumn{2}{|c|}{ Factor 4} & \multicolumn{2}{|c|}{ Factor 5} & \multicolumn{2}{|c|}{ SATT } \\
\hline & & $\mathbf{N}$ & M & SD & $\mathbf{M}$ & SD & $\mathbf{M}$ & SD & $\mathbf{M}$ & SD & M & SD & M \\
\hline 0 & 8 & 3.83 & 0.93 & 2.97 & 0.62 & 3.47 & 0.67 & 3.50 & 0.58 & 3.56 & 0.42 & 3.47 & 0.54 \\
\hline 1 & 3 & 3.47 & 0.50 & 3.92 & 0.58 & 4.08 & 0.38 & 3.92 & 0.52 & 4.33 & 0.29 & 3.88 & 0.11 \\
\hline 2 & 9 & 3.64 & 0.99 & 3.78 & 0.46 & 3.89 & 0.77 & 3.89 & 0.44 & 3.89 & 0.55 & 3.80 & 0.46 \\
\hline 3 & 9 & 4.58 & 0.39 & 3.81 & 0.74 & 3.81 & 0.63 & 4.28 & 0.70 & 4.33 & 0.79 & 4.16 & 0.30 \\
\hline 4 & 28 & 3.96 & 0.70 & 3.95 & 0.77 & 3.89 & 0.74 & 3.78 & 0.74 & 3.84 & 0.88 & 3.89 & 0.52 \\
\hline
\end{tabular}

*0: No use, 1: Rarely on certain topics, 2: Several times a month, 3: Several times a week, 4: Almost in every lesson

According to the Roys Largest Root $\Theta=.351, \mathrm{~F}(5,51)=3.582, \mathrm{p}<.01$ statistics obtained in MANOVA, it was concluded that ATTT demonstrated a significant difference according to the frequency of using technological tools in lessons. ANOVA test (Table 6) showed that the attitudes of teachers using technological tools "almost in every lesson" towards technology were significantly higher than those of the teachers who did not use technology in lessons in the "using technological tools in education" factor $(F(4,56)=3.123, \mathrm{p}<.05$, Partial $\eta 2=.194)$.

Table 6. ANOVA results according to the frequency at which teachers use technological tools in lessons

\begin{tabular}{|c|c|c|c|c|c|c|c|c|}
\hline Variance & & Sum of Squares & df & Mean Square & $\mathbf{F}$ & $\mathbf{p}$ & Partial $\eta^{2}$ & Bonferroni" \\
\hline \multirow{3}{*}{ Factor 1} & Between G. & 5.206 & 4 & 1.302 & 2.350 & .066 & .153 & \\
\hline & Within G. & 28.804 & 52 & .554 & & & & \\
\hline & Total & 34.010 & 56 & & & & & \\
\hline \multirow{3}{*}{ Factor 2} & Between G. & 6.077 & 4 & 1.519 & 3.123 & .022 & .194 & $4>0$ \\
\hline & Within G. & 25.294 & 52 & .486 & & & & \\
\hline & Total & 31.371 & 56 & & & & & \\
\hline \multirow{3}{*}{ Factor 3} & Between G. & 1.384 & 4 & .346 & .688 & .603 & .050 & \\
\hline & Within G. & 26.136 & 52 & .503 & & & & \\
\hline & Total & 27.520 & 56 & & & & & \\
\hline \multirow{3}{*}{ Factor 4} & Between G. & 2.800 & 4 & .700 & 1.572 & .196 & .108 & \\
\hline & Within G. & 23.154 & 52 & .445 & & & & \\
\hline & Total & 25.954 & 56 & & & & & \\
\hline \multirow{3}{*}{ Factor 5} & Between G. & 3.260 & 4 & .815 & 1.422 & .240 & .099 & \\
\hline & Within G. & 29.801 & 52 & .573 & & & & \\
\hline & Total & 33.061 & 56 & & & & & \\
\hline \multirow{3}{*}{ SATT } & Between G. & 2.086 & 4 & .522 & 2.302 & .071 & .150 & \\
\hline & Within G. & 11.784 & 52 & 0.227 & & & & \\
\hline & Total & 13.871 & 56 & & & & & \\
\hline
\end{tabular}

*0: No use, 1: Rarely on certain topics, 2: Several times a month, 3: Several times a week,

4: Almost in every lesson

In the study, it was also investigated whether ATTT differ by age. The mean scores obtained by the mathematics teachers in SATT according to their ages are displayed in Table 7.

Table 7. SATT scores of teachers according to their ages

\begin{tabular}{llllllllllllll}
\hline \multirow{2}{*}{ Age } & \multicolumn{3}{c}{ Factor 1 } & \multicolumn{2}{c}{ Factor 2 } & \multicolumn{2}{c}{ Factor 3 } & \multicolumn{2}{c}{ Factor 4 } & \multicolumn{2}{c}{ Factor 5 } & \multicolumn{2}{c}{ SATT } \\
\cline { 2 - 31 } & N & M & SD & M & SD & M & SD & M & SD & M & SD & M & SD \\
\hline $26-30$ & 3 & 4.67 & 0.58 & 4.33 & 0.58 & 4.08 & 0.38 & 4.33 & 0.58 & 2.83 & 1.26 & 4.21 & 0.28 \\
$31-35$ & 8 & 3.88 & 1.02 & 3.44 & 0.92 & 3.88 & 0.60 & 3.84 & 0.76 & 4.00 & 0.65 & 3.79 & 0.53 \\
$36-40$ & 27 & 3.87 & 0.79 & 3.89 & 0.68 & 3.92 & 0.61 & 3.94 & 0.56 & 4.09 & 0.52 & 3.92 & 0.44 \\
$41+$ & 19 & 4.02 & 0.66 & 3.62 & 0.74 & 3.64 & 0.88 & 3.62 & 0.79 & 3.79 & 0.92 & 3.75 & 0.57 \\
\hline
\end{tabular}


According to MANOVA, it was understood that ATTT differed significantly according to age (Hotelling's Trace $\mathrm{T}=.557, \mathrm{~F}(15,143)=1.769, \mathrm{p}<.05$; Roys Largest Root $\Theta=.415, \mathrm{~F}(5,51)=$ $4.238, \mathrm{p}<.01$ ). Looking at the ANOVA values in Table 8 , it was understood that there was a significant difference between the teachers in the 36-40 age group and those in the 26-30 age group, in favour of the 36-40 age group in the "evaluation of technological tools" factor $(\mathrm{F}(3,53)=2.941, \mathrm{p}<.05$, Partial $\eta 2=.143)$.

Table 8. ANOVA results according to the ages of teachers

\begin{tabular}{|c|c|c|c|c|c|c|c|c|}
\hline Variance & & $\begin{array}{l}\text { Sum of } \\
\text { Squares }\end{array}$ & df & $\begin{array}{l}\text { Mean } \\
\text { Square }\end{array}$ & $\mathbf{F}$ & $\mathbf{p}$ & Partial $\eta^{2}$ & Bonferroni \\
\hline \multirow{3}{*}{ Factor 1} & Between G. & 1.825 & 3 & .608 & 1.002 & .399 & .054 & \\
\hline & Within G. & 32.185 & 53 & .607 & & & & \\
\hline & Total & 34.010 & 56 & & & & & \\
\hline \multirow{3}{*}{ Factor 2} & Between G. & 2.647 & 3 & .882 & 1.628 & . 194 & .084 & \\
\hline & Within G. & 28.723 & 53 & .542 & & & & \\
\hline & Total & 31.371 & 56 & & & & & \\
\hline \multirow{3}{*}{ Factor 3} & Between G. & 1.064 & 3 & .355 & .710 & .550 & .039 & \\
\hline & Within G. & 26.456 & 53 & .499 & & & & \\
\hline & Total & 27.520 & 56 & & & & & \\
\hline \multirow{3}{*}{ Factor 4} & Between G. & 1.957 & 3 & .652 & 1.441 & .241 & .075 & \\
\hline & Within G. & 23.997 & 53 & .453 & & & & \\
\hline & Total & 25.954 & 56 & & & & & \\
\hline \multirow{3}{*}{ Factor 5} & Between G. & 4.718 & 3 & 1.573 & 2.941 & .041 & .143 & \\
\hline & Within G. & 28.343 & 53 & .535 & & & & $36-40>26-30$ \\
\hline & Total & 33.061 & 56 & & & & & \\
\hline \multirow{3}{*}{ SATT } & Between G. & .757 & 3 & .252 & 1.020 & .391 & .055 & \\
\hline & Within G. & 13.113 & 53 & 247 & & & & \\
\hline & Total & 13.871 & 56 & & & & & \\
\hline
\end{tabular}

How do teachers use technological tools in lessons and do the ATTT differ according to this usage?

According to the opinions of mathematics teachers, it was found that teachers mostly used technological tools to solve problems and exercises, or to project the lesson notes. The way teachers used technological tools in the lessons and some of their views on this subject are as follows (Table 9):
"I reflect the publication, which is the same as what we had students purchase, on the smartboard and I use it in solving the questions. I use a course notebook and use it to solve many questions."
"I used it for the lecture or problem solving that I obtained from the PDF files I found on the Internet. But students are bored with writing and solving questions. "
"We solve equations and draw graphics with Wolfram Alpha. By saving a document (exam questions etc.) on a smartphone and using it."

Table 9. The ways teachers use technological tools in their lessons

\begin{tabular}{ll}
\hline Usage & $\mathbf{N}$ \\
\hline Solve problems and exercises & 41 \\
Project the lesson notes & 32 \\
Figure or graph drawing & 8 \\
DGS or CAS usage & 2 \\
Animation & 2 \\
\hline
\end{tabular}

Looking at the ways teachers used technological tools in lessons, it was found that there was a variety of tools and programs used. While the majority of mathematics teachers (35 
participants) used only smartboards in their lessons, others (14 participants) used multiple technological tools. Technological tools used by teachers in their lessons are displayed in Table 10.

Table 10. Technological tools used by teachers in lessons

\begin{tabular}{ll}
\hline Technological tools & $\mathbf{N}$ \\
\hline Smartboard & 46 \\
Tablet Computer & 9 \\
Computer & 6 \\
Projection & 1 \\
Smart Phone & 1 \\
\hline
\end{tabular}

Also, the mean scores obtained by the teachers in SATT according to the variety of technological tools used in lessons are displayed in Table 11.

Table 11. SATT scores according to the variety of technological tools used by the teachers in lessons.

\begin{tabular}{|c|c|c|c|c|c|c|c|c|c|c|c|c|c|}
\hline \multirow{2}{*}{ Tools* } & & \multicolumn{2}{|c|}{ Factor 1} & \multicolumn{2}{|c|}{ Factor 2} & \multicolumn{2}{|c|}{ Factor 3} & \multicolumn{2}{|c|}{ Factor 4} & \multicolumn{2}{|c|}{ Factor 5} & \multicolumn{2}{|c|}{ SATT } \\
\hline & & $\mathbf{N}$ & $\mathbf{M}$ & SD & $\mathbf{M}$ & SD & $\mathbf{M}$ & SD & $\mathbf{M}$ & SD & $\mathbf{M}$ & SD & $\mathbf{M}$ \\
\hline 0 & 8 & 3.83 & 0.93 & 2.97 & 0.62 & 3.47 & 0.67 & 3.50 & 0.58 & 3.56 & 0.42 & 3.47 & 0.54 \\
\hline 1 & 35 & 3.89 & 0.78 & 3.96 & 0.67 & 3.85 & 0.77 & 3.76 & 0.68 & 3.91 & 0.86 & 3.87 & 0.51 \\
\hline 2 & 14 & 4.23 & 0.67 & 3.71 & 0.73 & 3.98 & 0.45 & 4.23 & 0.58 & 4.11 & 0.63 & 4.06 & 0.32 \\
\hline
\end{tabular}

*0: No use, 1: Used only smartboards, 2: Used multiple tools

MANOVA concluded that ATTT showed a significant difference according to the variety of technological tools used in lessons (Pillai's Trace $\mathrm{V}=.357, \mathrm{~F}(10,102)=2.220, \mathrm{p}<.01$ ). The statistics in Table 12 indicated that this difference was present in SATT in general $(\mathrm{F}(2,54)=3.870, \mathrm{p}<.05$, Partial $\eta 2=.125)$ and "using technological tools in education" $(\mathrm{F}(2,54)=6.918, \mathrm{p}<.01$, Partial $\eta 2=.204)$, "teaching how to use technological tools" $(F(2,54)=3.903, p<.05$, Partial $\eta 2=.126)$ factors of the SATT. Significant differences were observed in the "using technological tools in education" factor, favouring the teachers who "used multiple tools" and "used only smartboards" when compared to the teachers who did not use technological tools $(\mathrm{p}<.05)$. There were significant differences in SATT in general and in the "teaching how to use technological tools" factor, favouring the teachers who "used multiple tools" when compared to the teachers who did not use technological tools in their lessons.

Table 12. ANOVA results according to the variety of technological tools used by teachers in lessons.

\begin{tabular}{|c|c|c|c|c|c|c|c|c|}
\hline Variance & & Sum of Squares & df & Mean Square & $\mathbf{F}$ & $\mathbf{p}$ & $\begin{array}{l}\text { Partial } \\
\eta^{2}\end{array}$ & Bonferroni $^{*}$ \\
\hline \multirow{3}{*}{ Factor 1} & Between G. & 1.319 & 2 & .659 & 1.089 & .344 & .039 & \\
\hline & Within G. & 32.691 & 54 & .605 & & & & \\
\hline & Total & 34.010 & 56 & & & & & \\
\hline \multirow{3}{*}{ Factor 2} & Between G. & 6.398 & 2 & 3.199 & 6.918 & .002 & .204 & \multirow{3}{*}{$1>0,2>0$} \\
\hline & Within G. & 24.973 & 54 & .462 & & & & \\
\hline & Total & 31.371 & 56 & & & & & \\
\hline \multirow{3}{*}{ Factor 3} & Between G. & 1.382 & 2 & .691 & 1.428 & .249 & .050 & \\
\hline & Within G. & 26.138 & 54 & .484 & & & & \\
\hline & Total & 27.520 & 56 & & & & & \\
\hline \multirow{3}{*}{ Factor 4} & Between G. & 3.278 & 2 & 1.639 & 3.903 & .026 & .126 & \multirow{3}{*}{$2>0$} \\
\hline & Within G. & 22.676 & 54 & .420 & & & & \\
\hline & Total & 25.954 & 56 & & & & & \\
\hline
\end{tabular}




\begin{tabular}{lllllllll}
\hline \multirow{2}{*}{ Factor 5 5 } & Between G. & 1.511 & 2 & .755 & 1.293 & .283 & .046 \\
& Within G. & 31.551 & 54 & .584 & & & & \\
& Total & 33.061 & 56 & & & & & $2>0$ \\
\multirow{3}{*}{ SATT } & Between G. & 1.739 & 2 & .869 & 3.870 & .027 & .125 & \\
& Within G. & 12.132 & 54 & .225 & & & & \\
& Total & 13.871 & 56 & & & & & \\
\hline
\end{tabular}

*0: No use, 1: Used only smartboards, 2: Used multiple tools

Additionally, looking at the ways teachers used technological tools in lessons it was observed that teachers mostly used PDF readers, which visualized the lesson notes; presentations software such as MS PowerPoint; and word processors such as MS Word (Table 13). It was also observed that very few of the teachers used the dynamic geometry software (DGS) called GeoGebra used for teaching mathematics or the computer algebra system (CAS) called Mathematica.

Table 13. Software used by teachers in their lessons

\begin{tabular}{ll}
\hline Software & $\mathbf{N}$ \\
\hline PDF reader & 39 \\
Presentation software & 27 \\
Word processor & 18 \\
Multimedia player & 14 \\
GeoGebra & 2 \\
Mathematica & 1 \\
Other & 2 \\
\hline
\end{tabular}

While some of the mathematics teachers used only one software in lessons, the majority used multiple software. According to the variety of software used by teachers in lessons, the mean of SATT is displayed in Table 14.

Table 14. SATT scores according to the variety of computer software used by teachers in lessons

\begin{tabular}{llllllllllllll}
\hline \multirow{2}{*}{ Prg. } & \multicolumn{4}{c}{ Factor 1 } & \multicolumn{1}{c}{ Factor 2 } & \multicolumn{2}{c}{ Factor 3 } & \multicolumn{2}{c}{ Factor 4 } & \multicolumn{2}{c}{ Factor 5 } & \multicolumn{2}{c}{ SATT } \\
\cline { 2 - 16 } & N & M & SD & M & SD & M & SD & M & SD & M & SD & M & N \\
\hline 0 & 8 & 3.83 & 0.93 & 2.97 & 0.62 & 3.47 & 0.67 & 3.50 & 0.58 & 3.56 & 0.42 & 3.47 & 0.54 \\
1 & 16 & 3.71 & 0.77 & 3.77 & 0.67 & 3.73 & 0.88 & 3.28 & 0.66 & 3.75 & 0.95 & 3.64 & 0.59 \\
2 & 33 & 4.12 & 0.73 & 3.95 & 0.70 & 3.96 & 0.58 & 4.20 & 0.47 & 4.08 & 0.71 & 4.06 & 0.33 \\
\hline
\end{tabular}

*0: No use; 1: Single software; 2: Multiple software

MANOVA concluded that ATTT showed a significant difference according to the variety of programs they used in lessons (Pillai's Trace $\mathrm{V}=.587, \mathrm{~F}(10,102)=4.237, \mathrm{p}<.01$ ). Statistics in Table 15 showed that this difference was present in the $(\mathrm{F}(2,54)=8.453, \mathrm{p}<.01$, Partial $\eta 2=.238)$, "using technological tools in education" $(\mathrm{F}(2,54)=6.601, \mathrm{p}<.01$, Partial $\eta 2=.196)$ and "teaching how to use technological tools" $(\mathrm{F}(2,54)=17.270, \mathrm{p}<.01$, Partial $\eta 2=.390)$ factors of the SATT. A significant difference was observed in the "using technological tools in education" factor, favouring the teachers who used "multiple" software and a "single" software when compared to the teachers who did not use technological tools in their lessons ( $\mathrm{p}<.05)$. There were significant differences in SATT in general and in the "teaching how to use technological tools" factor, favouring the teachers who used "multiple" software when compared to the teachers who used a "single" software in lessons $(\mathrm{p}<.05)$. 
Table 15. ANOVA results according to the variety of computer software used by teachers in lessons.

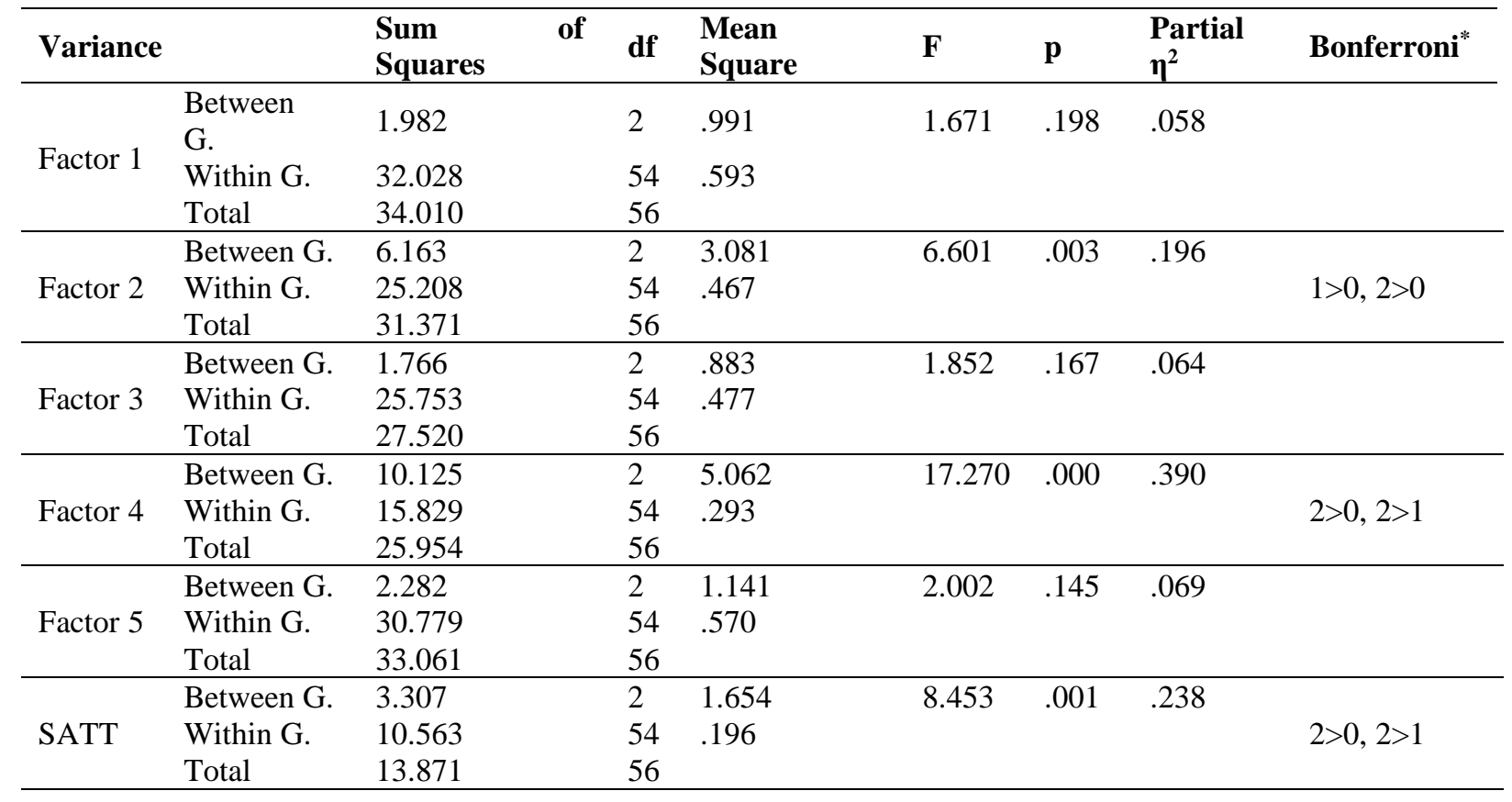

*0: No use; 1: Single software; 2: Multiple software

What are the opinions of teachers about the use of technological tools by the students and do the ATTT differ according to these opinions?

It was concluded that the majority of mathematics teachers (34 participants) were negative towards the use of technological tools by students in their lessons or they were neutral (8 participants). It was observed that these negative opinions decreased (20 participants) when it came to the use of the technological tools by the students for lesson preparation outside the classroom.

One of the opinions of the teachers were neutral towards the use of technological tools by the students and one of the opinions of the teachers who were positive towards this issue are given below:

"I sometimes consider it positive and sometimes negative. It would be nice if technology were used moderately. It should not be exaggerated. Today, there are many schools in the West that see the damages of technology and return to the blackboard, and it seems to be popular now."

"It will be very useful to use if the computer and tablet computer contain appropriate programs. It will provide a better understanding of the problem in questions that require more problem solving and visuality in lessons."

According to the opinions of teachers, the reason for being negative towards the use of technology by students was that these tools were used outside of their purpose; they did not contribute to the teaching of mathematics; and students were not prepared to use such applications (Table 16). Some of the teacher opinions on this issue were as follows:

"[Using] Tablets mean nothing more than a game for the student. At the same time, even smartphones are the same, I personally do not find it appropriate...[Students] They used to be more motivated in the previous system. ...As I said, a student, who is not motivated, 
makes noise and sabotages the lesson, and I don't think the student is ready to use technology."

"I do not think the use of technology is very beneficial in my field except for some topics... I do not allow them to use it during the lesson. Because our school infrastructure and my knowledge of technology are not sufficient. ...The main issue is that I am not sufficient in this regard as I had not been trained about this when I became a teacher. More technology training should be provided in education faculties. '"

"I do not find it appropriate for students to do homework on the internet in numerical lessons. They have to do homework by researching and writing it down themselves. They just take the information and bring it. So they bring it without reading, researching or analysing. So this is free riding. It makes no sense. "

Table 16. Opinions of teachers about why students should not use technological tools

\begin{tabular}{lc}
\hline Opinions & $\mathbf{N}$ \\
\hline Use outside of their purpose & 16 \\
No contribution to mathematics education & 12 \\
Students not prepared for technology applications & 6 \\
Student's getting used to ready-made things & 5 \\
Distraction & 4 \\
Difficulty in classroom control & 3 \\
Time consuming & 3 \\
Lack of equipment & 3 \\
Lack of technology knowledge & 2 \\
\hline
\end{tabular}

On the other hand, SATT means of mathematics teachers about their opinions on the use of technological tools by the students in the lessons are displayed in Table 17.

Table 17. SATT scores of teachers according to their opinions on the use of technological tools by the students in their lessons

\begin{tabular}{|c|c|c|c|c|c|c|c|c|c|c|c|c|c|}
\hline \multirow{2}{*}{ Opn. } & \multicolumn{3}{|c|}{ Factor 1} & \multicolumn{2}{|c|}{ Factor 2} & \multicolumn{2}{|c|}{ Factor 3} & \multicolumn{2}{|c|}{ Factor 4} & \multicolumn{2}{|c|}{ Factor 5} & \multicolumn{2}{|c|}{ SATT } \\
\hline & $\mathbf{N}$ & $\mathbf{M}$ & SD & $\mathbf{M}$ & SD & $\mathbf{M}$ & SD & $\mathbf{M}$ & SD & $\mathbf{M}$ & SD & $\mathbf{M}$ & $\mathbf{N}$ \\
\hline 0 & 34 & 3.85 & 0.83 & 3.73 & 0.79 & 3.76 & 0.80 & 3.61 & 0.73 & 3.94 & 0.81 & 3.76 & 0.57 \\
\hline 1 & 8 & 4.58 & 0.63 & 4.28 & 0.41 & 4.22 & 0.54 & 4.19 & 0.44 & 3.56 & 1.02 & 4.25 & 0.20 \\
\hline 2 & 15 & 3.89 & 0.60 & 3.55 & 0.70 & 3.78 & 0.46 & 4.18 & 0.44 & 4.03 & 0.44 & 3.87 & 0.32 \\
\hline
\end{tabular}

*0: Negative, 1: Neutral, 2: Positive

MANOVA (Pillai's Trace V=3.397, $\mathrm{F}(10,102)=3.047, \mathrm{p}<.01$ ) concluded that ATTT showed a significant difference according to their opinions about the use of technological tools by the students in the lessons. ANOVA statistics in Table 18 indicated a significant difference in favour of the teachers who had a "positive" opinion in the "teaching how to use technological tools" factor $(\mathrm{F}(2,54)=5.706, \mathrm{p}<.01$, Partial $\eta 2=.174)$. A significant difference was found in SATT in general between teachers with "negative" and "neutral" opinions, favouring teachers with "neutral" opinions $(F(2,54)=3.343, p<.05$, Partial $\eta 2=.110)$.

Table 18. ANOVA results according to the opinions of teachers about the use of technological tools by the students in lessons

\begin{tabular}{lllllllll}
\hline Variance & & Sum of Squares & df & Mean Square & $\mathbf{F}$ & $\mathbf{p}$ & $\begin{array}{l}\text { Partial } \\
\boldsymbol{\eta}^{2}\end{array}$ & Bonferroni* $^{*}$ \\
\hline \multirow{2}{*}{ Factor 1 1 } & Between G. & 3.481 & 2 & 1.740 & 3.078 & .054 & .102 & \\
& Within G. & 30.529 & 54 & .565 & & & & \\
& Total & 34.010 & 56 & & & & & \\
\hline \multirow{2}{*}{ Factor 2 } & Between G. & 2.870 & 2 & 1.435 & 2.719 & .075 & .091 & \\
& Within G. & 28.501 & 54 & .528 & & & & \\
& Total & 31.371 & 56 & & & & & \\
\hline
\end{tabular}




\begin{tabular}{lllllllll}
\hline \multirow{2}{*}{ Factor 3 3} & Between G. & 1.421 & 2 & .711 & 1.470 & .239 & .052 & \\
& Within G. & 26.099 & 54 & .483 & & & & \\
& Total & 27.520 & 56 & & & & & \\
\hline \multirow{3}{*}{ Factor 4 } & Between G. & 4.528 & 2 & 2.264 & 5.706 & .006 & .174 & \\
& Within G. & 21.426 & 54 & .397 & & & & $2>0$ \\
& Total & 25.954 & 56 & & & & & \\
\hline \multirow{4}{*}{ Factor 5 5 } & Between G. & 1.227 & 2 & .613 & 1.041 & .360 & .037 & \\
& Within G. & 31.834 & 54 & .590 & & & & \\
& Total & 33.061 & 56 & & & & & \\
\hline \multirow{3}{*}{ SATT } & Between G. & 1.528 & 2 & .764 & 3.343 & .043 & .110 & \\
& Within G. & 12.342 & 54 & .229 & & & & $1>0$ \\
& Total & 13.871 & 56 & & & & & \\
\hline
\end{tabular}

*0: Negative, 1: Neutral, 2: Positive

The SATT means of mathematics teachers regarding their opinions on the use of technological tools by the students for activities, such as studying and doing homework outside the classroom, are displayed in Table 19.

Table 19. The SATT scores of teachers regarding their opinions on the use of technological tools by the students for preparing

\begin{tabular}{|c|c|c|c|c|c|c|c|c|c|c|c|c|c|}
\hline \multirow{2}{*}{ Opn. ${ }^{*}$} & \multicolumn{3}{|c|}{ Factor 1} & \multicolumn{2}{|c|}{ Factor 2} & \multicolumn{2}{|c|}{ Factor 3} & \multicolumn{2}{|c|}{ Factor 4} & \multicolumn{2}{|c|}{ Factor 5} & \multicolumn{2}{|c|}{ SATT } \\
\hline & $\mathbf{N}$ & M & SD & $\mathbf{M}$ & SD & M & SD & M & SD & $\mathbf{M}$ & SD & $\mathbf{M}$ & $\mathbf{N}$ \\
\hline 0 & 20 & 3.91 & 0.91 & 3.59 & 0.70 & 3.71 & 0.89 & 3.53 & 0.76 & 3.80 & 0.78 & 3.71 & 0.59 \\
\hline 1 & 37 & 3.99 & 0.71 & 3.85 & 0.76 & 3.89 & 0.58 & 4.01 & 0.58 & 3.97 & 0.76 & 3.94 & 0.43 \\
\hline
\end{tabular}

*0: Negative, 1: Positive

The Pillai's Trace $\mathrm{V}=.129, \mathrm{~F}(5,51)=1.511, \mathrm{p}>.05$ statistics obtained from MANOVA indicated that ATTT did not differ significantly according to the opinions on the use of technological tools by the students for preparing for lesson. However, according to ANOVAs (Table 20) performed after the Bonferroni correction, a significant difference was found in favour of teachers with positive opinions in the "teaching how to use technological tools" factor $(F(1,55)=7.456, p<.008$, Partial $\eta 2=.119)$.

Table 20. ANOVA results according to the opinions of teachers about the use of technological tools by the students for preparing

\begin{tabular}{|c|c|c|c|c|c|c|c|c|}
\hline Variance & & Sum of Squares & df & Mean Square & $\mathbf{F}$ & $\mathbf{p}^{*}$ & $\begin{array}{l}\text { Partial } \\
\eta^{2}\end{array}$ & Difference $^{* *}$ \\
\hline \multirow{3}{*}{ Factor 1} & Between G. & .093 & 1 & .093 & .151 & .699 & .003 & \\
\hline & Within G. & 33.917 & 55 & .617 & & & & \\
\hline & Total & 34.010 & 56 & & & & & \\
\hline \multirow{3}{*}{ Factor 2} & Between G. & .904 & 1 & .904 & 1.632 & .207 & .029 & \\
\hline & Within G. & 30.467 & 55 & .554 & & & & \\
\hline & Total & 31.371 & 56 & & & & & \\
\hline \multirow{3}{*}{ Factor 3} & Between G. & .418 & 1 & .418 & .848 & .361 & .015 & \\
\hline & Within G. & 27.102 & 55 & .493 & & & & \\
\hline & Total & 27.520 & 56 & & & & & \\
\hline \multirow{3}{*}{ Factor 4} & Between G. & 3.098 & 1 & 3.098 & 7.456 & .008 & .119 & \\
\hline & Within G. & 22.856 & 55 & .416 & & & & $1>0$ \\
\hline & Total & 25.954 & 56 & & & & & \\
\hline \multirow{3}{*}{ Factor 5} & Between G. & .388 & 1 & .388 & .654 & .422 & .012 & \\
\hline & Within G. & 32.673 & 55 & .594 & & & & \\
\hline & Total & 33.061 & 56 & & & & & \\
\hline \multirow{3}{*}{ SATT } & Between G. & .727 & 1 & .727 & 3.042 & .087 & .052 & \\
\hline & Within G. & 13.144 & 55 & .239 & & & & \\
\hline & Total & 13.871 & 56 & & & & & \\
\hline
\end{tabular}

${ }^{*} \alpha=.008 ;{ }^{* *} 0$ : Negative, 1 : Positive 
What kind of training did teachers receive on the use of technology in lessons and do the ATTT differ according to these trainings?

It was found that 40 teachers received training on using technology in lessons at the university or through in-service training during their professional life, and, 17 of them did not receive any training. Contents of trainings received (Table 21) showed that majority of the teachers participated in the in-service trainings on the use of smartboards within the scope of the FATIH Project. Some opinions of teachers about the content of the trainings they received on using technology were as follows:

"I took it as a course at the university. I also attended a course on using computers."

"The use of smart boards, graphic drawings, Windows, Office within the scope of the FATIH Project... I received some of these trainings, but I realized that it was not very successful in student applications. "

"The courses I have taken are both inadequate and wasted because there were no applied practices during the courses."

Table 21. Contents of the trainings received by teachers

\begin{tabular}{ll}
\hline Contents & $\mathbf{N}$ \\
\hline Smartboard usage & 30 \\
Basic computer usage & 12 \\
DGS or CAS training & 8 \\
Computer programming & 7 \\
Computer assisted instruction & 4 \\
\hline
\end{tabular}

Also, the SATT scores of mathematics teachers according their past training on using technology in lessons are displayed in Table 22.

Table 22. SATT scores of teachers according to their past training on usage of technology in lessons

\begin{tabular}{|c|c|c|c|c|c|c|c|c|c|c|c|c|c|}
\hline \multirow{2}{*}{ Trn.* } & \multicolumn{3}{|c|}{ Factor 1} & \multicolumn{2}{|c|}{ Factor 2} & \multicolumn{2}{|c|}{ Factor 3} & \multicolumn{2}{|c|}{ Factor 4} & \multicolumn{2}{|c|}{ Factor 5} & \multicolumn{2}{|c|}{ SATT } \\
\hline & $\mathbf{N}$ & M & SD & M & SD & M & SD & M & SD & M & SD & M & $\mathbf{N}$ \\
\hline Yes & 40 & 4.00 & 0.79 & 3.76 & 0.79 & 3.76 & 0.78 & 3.89 & 0.73 & 3.88 & 0.84 & 3.86 & 0.54 \\
\hline No & 17 & 3.88 & 0.77 & 3.75 & 0.65 & 3.99 & 0.43 & 3.72 & 0.55 & 4.00 & 0.59 & 3.85 & 0.38 \\
\hline
\end{tabular}

As a result of MANOVA, it was understood that the attitudes of teachers did not differ significantly according to their training on using technology in their lessons (Pillai's Trace $\mathrm{V}=.0831, \mathrm{~F}(5,51)=.918, \mathrm{p}>.05)$. Similarly, no differences were found by the follow-up tests (Table 23) (p>.008).

Table 23. ANOVA results of teachers according to their training on using technology in lessons

\begin{tabular}{|c|c|c|c|c|c|c|c|}
\hline Variance & & Sum of Squares & df & Mean Square & $\mathbf{F}$ & $\mathbf{p}^{*}$ & Partial $\eta^{2}$ \\
\hline \multirow{3}{*}{ Factor 1} & Between G. & .165 & 1 & .165 & .268 & .607 & .005 \\
\hline & Within G. & 33.845 & 55 & .615 & & & \\
\hline & Total & 34.010 & 56 & & & & \\
\hline \multirow{3}{*}{ Factor 2} & Between G. & .002 & 1 & .002 & .003 & .955 & .000 \\
\hline & Within G. & 31.369 & 55 & .570 & & & \\
\hline & Total & 31.371 & 56 & & & & \\
\hline \multirow{3}{*}{ Factor 3} & Between G. & .592 & 1 & .592 & 1.210 & .276 & .022 \\
\hline & Within G. & 26.928 & 55 & .490 & & & \\
\hline & Total & 27.520 & 56 & & & & \\
\hline \multirow{3}{*}{ Factor 4} & Between G. & .358 & 1 & .358 & .769 & .384 & .014 \\
\hline & Within G. & 25.596 & 55 & .465 & & & \\
\hline & Total & 25.954 & 56 & & & & \\
\hline
\end{tabular}




\begin{tabular}{llllllll}
\hline \multirow{2}{*}{ Factor 5 5 } & Between G. & .186 & 1 & .186 & .312 & .579 & .006 \\
& Within G. & 32.875 & 55 & .598 & & & \\
& Total & 33.061 & 56 & & & & \\
\hline \multirow{2}{*}{ SATT } & Between G. & .001 & 1 & .001 & .005 & .945 & .000 \\
& Within G. & 13.869 & 55 & .252 & & & \\
& Total & 13.871 & 56 & & & & \\
\hline$* \alpha=.008$ & & & & & & &
\end{tabular}

\section{Discussion and Conclusion}

While the majority of the mathematics teachers who participated in the research used technological tools frequently in their lessons, a significant number of them either made a limited use of them or they did not use technology at all. Looking at the scores obtained by the teachers from SATT and its factors, it was understood that their attitudes towards technology were "positive." This result coincides with the results of various studies conducted with teachers (Çakır \& Oktay, 2013; Üstün \& Akman, 2015) or preservice teachers (Birkollu et al., 2017; Kayalar, 2018; Paşa et al., 2015). When the attitudes of mathematics teachers towards technology were evaluated in terms of age, it was understood that in the "evaluating technological tools" factor, teachers in the 36-40 age group ( $\mathrm{M}=4.09$, "positive") had a more positive attitude than teachers in the 26-30 age group ( $M=2.83$, "neutral"). It is noteworthy that the teachers between the ages of 26-30 actually had the highest means in overall SATT and all factors except for the factor mentioned above. This was because the younger teachers demonstrated low participation $(\mathrm{M}=2.66$, "neutral") in the item "technological tools could succeed only if they address all senses." It can be argued that the attitudes of younger teachers towards technology were high; however, they had a different pedagogical understanding towards the use of technology in lessons when compared to the experienced teachers.

When the reasons why mathematics teachers did not use technological tools were investigated, "lack of hardware," which was defined as one of the external barriers by Ertmer (1999) stood out in first place. That said, when the reasons why teachers did not use technological tools were considered within a holistic approach, it can be argued that this was mainly due to internal barriers such as finding these applications "useless" or thinking that they were "not suitable for mathematics lessons." The significant difference and large impact size observed against the teachers who "did not use technology in their classes" in the "using technological tools in education" factor was supportive of this finding. Teachers who scored higher in this factor were expected to have a positive attitude towards the necessity and importance of using technology in educational activities and towards the idea that these activities would contribute to the learning outcomes. However, it was understood that teachers who did not use technological tools in lessons had a "medium" $(M=2.97)$ level attitude in this factor.

Looking at the ways mathematics teachers used technological tools, it was found that they used technological tools such as smartboards instead of the traditional teaching tools such as chalkboards, and they used these tools in order to do exercises or project lecture notes. It was notable that the majority of teachers did not use a technological tool other than smartboards in lessons. Looking at ATTT in this context, it was observed that the teachers who used "only the smartboards" in lessons differed positively from the teachers who "did not use technological tools in lessons" in the "using technological tools in education" factor. However, teachers who used "multiple tools" differed positively from the teachers who "did not use technological tools in lessons" in the "teaching how to use technological tools" factor and the overall SATT. It can be concluded that the variety of technological tools used by 
mathematics teachers in lessons had a positive effect on their ATTT. A similar conclusion could be obtained for the variety of software used in lessons. Very few teachers used DGS and CAS software such as GeoGebra or Mathematica for teaching mathematics in lessons. The majority used the PDF reader and presentation software, which limited student interaction or did not allow it at all. It is striking that the variety of software used despite the limitation had a positive and large impact on ATTT. The reason why the majority of teachers did not use programs such as GeoGebra and Mathematica, as mentioned in previous studies, may be that they did not receive any training about these software and thus felt incompetent (Ardıç \& İşleyen, 2017b, 2017c; Birgin, Uzun \& Akar, 2020). The fact that the teachers who used multiple software in their lessons differed from other teachers with the largest impact size in terms of their attitudes towards technology in the "teaching how to use technological tools" factor is supportive of this result. Those who scored higher in this factor were expected to have a positive attitude towards the provision of training on using technology offered to preservice teachers during the education programs and to the teachers within the scope of inservice training.

In the study, it was also found that a majority of the mathematics teachers either did not favour students using technological tools in lessons or they were neutral towards this issue. There was a significant increase in the positive opinions when the question was about the use of technology by the students outside the classroom to prepare for lessons, and alike. It was found that teachers were negative about the use of tools such as computers and tablets because they were used outside of their purposes; they did not contribute to mathematics education; and students were not prepared for such applications. It is possible to reach similar findings, particularly as regards the opinion of "the use of tablet computers outside of their purpose," in many studies conducted in schools within the scope of the FATIH Project (Altın \& Kalelioğlu, 2015; Demirer \& Dikmen, 2018; Keleş, Öksüz \& Bahçekapıl1, 2013). This may stem from the fact that the teachers and students did not know how to use these technologies specifically in mathematics lessons. Hence, the dramatic changes observed in the opinions of teachers about using technological tools in lessons or outside the classroom may have indicated that they felt neutral towards this subject and believed that they or their students were not qualified to use these tools. The significant highness of the means of the teachers with "neutral" opinions in the analysis performed on their attitudes towards technology is supportive of this outcome. In addition, the fact that the teachers with positive opinions about the use of technological tools in lessons and outside the classroom had a significantly high attitude in the "teaching how to use technological tools" factor indicated that both teachers and students required training in this regard.

It was concluded that the majority of mathematics teachers who participated in the study received training on using technology in lessons at the university or as part of an in-service training during their profession. It is remarkable that a significant amount of the teachers who participated in the research (17 participants) stated that they did not receive any training on using technology. In fact, in-service training was organized for all teachers, particularly secondary education teachers, within the FATIH Project. This may indicate that the in-service trainings organized during the project did not reach the targeted prevalence. When the contents of these trainings were examined, it was concluded that almost all of the teachers were trained about the use of smartboards or basic computers, while a few of them were trained on computer-assisted teaching and DGSs or CASs. As some participants also stated, the trainings that the vast majority of teachers received touched only upon the technical features of the tools and how to use them, and that there were no practices or trainings on using technology in mathematics teaching. It can be argued that these trainings increased the 
knowledge levels of the teachers; however, they were not sufficient to create the desired level of impact on using technology in mathematics teaching. In this context, the fact that no significant difference was found contrary to what was expected when the attitudes of mathematics teachers towards technology were examined according to their previous training on using technology in the lessons is supportive of this conclusion. Findings indicating that the in-service trainings organized within the scope of the FATIH Project in previous studies were insufficient to eliminate the concerns, negative opinions or prejudices of the participants regarding the use of technology (Ardıç \& İşleyen, 2017b; Keleş et al., 2013; Keleş \& Turan, 2015) and that they did not contribute to achieving technology integration in mathematics teaching at the desired level (Ardıç \& İşleyen, 2017a) also support the conclusions of this study.

Overall results of the study indicated that mathematics teachers often used only smartboards in lessons; they did not use hardware such as tablet computers or software like DGS and CAS, in which students could interact; and they preferred teacher-centered classroom organizations. This could be interpreted as the fact that the trainings received by teachers did not have a desired level of impact on the way of using technological tools in their lessons and that the majority of teachers did not go far from the traditional understanding of teaching. The findings of many studies in the literature indicating that using technology in mathematics teaching replaced traditional methods and tools and (Bray \& Tangney, 2017; Egan et al., 2013; Ottenbreit-Leftwich et al., 2012; Thinyane, 2010) that only a basic level of technology could be used in this process (Ardıç \& İşleyen, 2017a; Avcı et al., 2019; Bray \& Tangney, 2017; Psycharis et al., 2013) supported these results. It can be argued that the "positive" ATTT had a positive effect on using technology in lessons. The results of the studies indicating that ATTT had a positive effect on the development of technological and pedagogical competencies of teachers are supportive of this conclusion (Albayrak Sar1 et al., 2016; Buabeng-Andoh, 2012; Çelik \& Yeşilyurt, 2013; Hill \& Uribe-Florez, 2020; Kalemoğlu Varol, 2015; Yulisman et all., 2019).

\section{Recommendations}

Among the significant differences and impact sizes observed in the SATT scores, it was noteworthy that differences were observed in the "using technological tools in education" and "teaching how to use technological tools" factors, in favour of teachers who used multiple technological tools and software. In other words, it can be argued that those teachers had positive attitudes that point to the fact that using technology in mathematics education was necessary and important; that these activities would contribute to the learning outcomes; and that teachers should be trained on the use of technology in both teacher training programs and in-service training. Rather than being taught the technical features of a technological tool, teachers and preservice teachers could be provided with practical trainings on different technological tools, which could enable students to also participate in the process during the educational activities, as well as software such as DGS and CAS, which they could use in mathematics education. Through these trainings, it can be ensured that mathematics teachers perform technology applications in their lessons where their students could get actively involved. While establishing the contents of the training programs to be conducted, integration frameworks such as Technological Pedagogical Content Knowledge (Koehler \& Mishra, 2005), where technology, pedagogy, and content knowledge are discussed together, can be utilized. Accordingly, new studies can be conducted on technology integration with mathematics education for determining the specific needs of teachers on technology, pedagogy and content knowledges. 
The findings of the study were limited to the data obtained from 57 mathematics teachers at 22 different high schools. Therefore, the data obtained from SATT were interpreted within an in-depth perspective together with the opinions of the teachers and by avoiding overgeneralization. Similar studies could be performed with larger sampling to obtain more generalized results.

\section{Acknowledgements}

Early version of this study was presented at the 4th International Turkish Computer and Mathematics Education Symposium in İzmir, Turkey, September 26-28, 2019.

\section{References}

Albayrak Sari, A., Canbazoglu Bilici, S., Baran, E., \& Ozbay, U. (2016). Investigating the relationship between teachers' technological pedagogical content knowledge (TPACK) competencies and attitudes towards information and communication technologies. Educational Technology Theory and Practice, 6(1), 1-21.

Altın, H. M., \& Kalelioğlu, F. (2015). Perceptions of students and teachers about FATIH project. Başkent University Journal of Education, 2(1), 89-105.

Ardıç, M. A., \& İşleyen, T. (2017a). High school teachers' levels of achieving technology integration and in-class reflections: The case of Mathematica. Universal Journal of Educational Research, 5(12B),1-17.

Ardıç, M. A., \& İşleyen, T. (2017b). High school mathematics teachers' views on computerassisted mathematics instruction through computer algebra systems in Turkey. European Journal of Education Studies, [S.1.], mar. 2017. Doi: 10.5281/zenodo.345626

Ardıç, M. A., \& İşleyen, T. (2017c). Secondary school mathematics teachers' and students' views on computer assisted mathematics instruction in Turkey: Mathematica example. Malaysian Online Journal of Educational Technology, 5(1), 46-64.

Avcı, Ü., Kula, A., \& Haşlaman, T. (2019). Teachers' opinions on technology that they want to integrate into the learning-teaching process. Acta Infologica, 3(1), 13-21.

Birgin, O., Uzun, K., \& Akar, S. G. M. (2020). Investigation of Turkish mathematics teachers' proficiency perceptions in using information and communication technologies in teaching. Education and Information Technologies, 25(1), 487-507.

Birkollu, S. S., Yucesoy, Y., Baglama, B., \& Kanbul, S. (2017). Investigating the attitudes of pre-service teachers towards technology based on various variables. TEM Journal, 6(3), 578.

Bray, A., \& Tangney, B. (2017). Technology usage in mathematics education research-A systematic review of recent trends. Computers \& Education, 114, 255-273.

Buabeng-Andoh, C. (2012). Factors influencing teachers adoption and integration of information and communication technology into teaching: A review of the literature. International Journal of Education and Development using ICT, 8(1), 136155.

Çakır, R., \& Oktay, S. (2013). Teachers' use of technology as becoming information society. The journal of the Industrial Arts Education Faculty of Gazi University, 30, 35-54.

Çelik, V., \& Yesilyurt, E. (2013). Attitudes to technology, perceived computer self-efficacy and computer anxiety as predictors of computer supported education. Computers \& Education, 60(1), 148-158. 
Creswell, J.W., \& Plano-Clark, V.L. (2011). Choosing a mixed methods design. In Designing and Conducting Mixed Methods Research (2nd ed.) (pp. 53-106). Thousand Oaks, CA: SAGE Publications, Inc.

Demirer, V., \& Dikmen, C. H. (2018). Investigation of teachers' opinions concerning FATİH project in the context of technological pedagogical content knowledge. Elementary Education Online, 17(1).

Egan, A., FitzGibbon, A., \& Oldham, E. (2013). Teacher Identified uses of technology in the classroom-an Irish cohort. In Society for Information Technology \& Teacher Education International Conference (pp. 5034-5039). Association for the Advancement of Computing in Education (AACE).

Ertmer, P. A. (1999). Addressing first-and second-order barriers to change: Strategies for technology integration. Educational technology research and development, 47(4), 4761.

Ertmer, P. A., Ottenbreit-Leftwich, A. T., Sadik, O., Sendurur, E., \& Sendurur, P. (2012). Teacher beliefs and technology integration practices: A critical relationship. Computers \& Education, 59, 423-435.

Field, A., 2009. Discovering statistics using SPSS. (3rd Edin.,). London: Sage

Göktas, Y., Gedik, N., \& Baydas, O. (2013). Enablers and barriers to the use of ICT in primary schools in Turkey: A comparative study of 2005-2011. Computers \& Education, 68, 211-222.

Hill, J. E., \& Uribe-Florez, L. (2020). Understanding secondary school teachers' TPACK and technology implementation in mathematics classrooms. International Journal of Technology in Education (IJTE), 3(1), 1-13.

Kağıtçıbaşı, Ç. (1999). Yeni insan ve insanlar sosyal psikolojiye giriş [New person and people introduction to social psychology]. İstanbul: Evrim Publishing House.

Kalemoğlu Varol, Y. (2015). Predictive power of prospective physical education teachers' attitudes towards educational technologies for their technological pedagogical content knowledge. International Journal of Progressive Education, 11(3), 7-19.

Kayalar, M. T. (2018). Examining pre-service teachers 'attitudes and interests in technology in terms of various variables. Journal of Social And Humanities Sciences Research (JSHSR), 5(27), 2753-2760.

Keles, E., \& Turan, E. (2015). Teachers' opinions on increasing opportunities and improving technology movement (FATİH). Turkish Journal of Education, 4(2), 17-28.

Keleş, E., Öksüz, B. D., \& Bahçekapıll, T. (2013). Teachers' opinions regarding the use of technology in education: Fatih project example. Gaziantep University Journal of Social Sciences, 12(2).

Koehler, M. J., \& Mishra, P. (2005). What happens when teachers design educational technology? The development of Technological Pedagogical Content Knowledge. Journal of Educational Computing Research, 32(2), 131-152.

MoNE, (2013). Ortaöğretim matematik dersi (9-12. Sinıflar) ögretim programı [Curriculum of secondary school mathematics lesson (9-12th classes)]. Retrieved on 20 July 2013 from http://ttkb.meb.gov.tr/program2.aspx?islem=1\&kno=219.

MoNE, (2020). Movement of enhancing opportunities and improving technology (FATIH) $\begin{array}{llllll}\text { Project. } & \text { Retrieved on } 17 & \text { February } & 2020 & \text { from }\end{array}$ http://fatihprojesi.meb.gov.tr/en/index.html.

Oskamp, S., \& Schultz, P. W. (2005). Attitudes and opinions. New Jersey: Lawrence Erlbaum Associates.

Ottenbreit-Leftwich, A. T., Brush, T. A., Strycker, J., Gronseth, S., Roman, T., Abaci, S., Plucker, J. (2012). Preparation versus practice: How do teacher education programs 
and practicing teachers align in their use of technology to support teaching and learning?. Computers \& Education, 59(2), 399-411.

Ottenbreit-Leftwich, A., Liao, J. Y. C., Sadik, O., \& Ertmer, P. (2018). Evolution of teachers' technology integration knowledge, beliefs, and practices: How can we support beginning teachers use of technology?. Journal of Research on Technology in Education, 50(4), 282-304.

Paşa, S., Bolat, Y., \& Karataş, F. (2015). Changes of the chemistry teacher candidates' attitudes towards and views about information and communication technologies: Chembiodraw application. Journal of Computer and Education Research, 3(6), 71-98.

Psycharis, S., Chalatzoglidis, G., \& Kalogiannakis, M. (2013). Moodle as a learning environment in promoting conceptual understanding for secondary school students. Eurasia Journal of Mathematics Science \& Technology Education, 9(1), 1121.

Thinyane, H. (2010). Are digital natives a world-wide phenomenon? An investigation into South African first year students' use and experience with technology. Computers \& Education, 55(1), 406-414.

Üstün, A., \& Akman, E. (2015). Private school teachers' attitudes and ideas about the utilization of technological tools in education (the example of Samsun province). Journal of Educational Science, 3(4), 94-103.

Yavuz, S. (2005). Developing a technology attitude scale for pre-service chemistry teachers. Turkish Online Journal of Educational Technology-TOJET, 4(1), 17-25.

Yulisman, H., Widodo, A., Riandi, R., \& Nurina, C. I. E. (2019). Moderated effect of teachers' attitudes to the contribution of technology competencies on TPACK. JPBI (Jurnal Pendidikan Biologi Indonesia), 5(2), 185-196. 